\title{
The Diagnostic Value of CD11b Expression on Peripheral Blood Neutrophils for Detection of Spontaneous Bacterial Peritonitis
}

\author{
Olfat M. Hendy ${ }^{1}$, Omkolsoum M. El Haddad ${ }^{2}$, Enas M. Ghoniem ${ }^{3}$, Karema A. Diab ${ }^{1}$, Fatma Omar Khalil ${ }^{3}{ }^{10}$, \\ Eman E. Elshemy ${ }^{4}$, Neamat Abdelmageed Abdelmageed ${ }^{4}$ and Mohamed H. Attia ${ }^{5, *(1)}$ \\ 1 Department of Clinical Pathology, National Liver Institute, Menoufia University, Shebin El-Kom 32511, Egypt; \\ olfat_hendy@hotmail.com (O.M.H.); karemadiab6@yahoo.com (K.A.D.) \\ 2 Department of Hepatology and Gastroenterology, National Liver Institute, Menoufia University, \\ Shebin El-Kom 32511, Egypt; dromkolsoum@yahoo.com \\ 3 Department of Clinical Microbiology and Immunology, National Liver Institute, Menoufia University, \\ Shebin El-Kom 32511, Egypt; enasghoniem@yahoo.com (E.M.G.); Fatma.khalil@liver.menofia.edu.eg (F.O.K.) \\ 4 Hepatogastroentrology \& Infectious Diseases-Faculty of Medicine for Girls, Internal Medicine Department, \\ AL-Azhar University, Nasr City, Cairo 11765, Egypt; Dr.emanelshemy@gmail.com (E.E.E.); \\ dr.neamatabdelmageed@yahoo.com (N.A.A.) \\ 5 Department of Internal Medicine, Faculty of Medicine, Ain Shams University, Cairo 11511, Egypt \\ * Correspondence: mohamed.atia@med.asu.edu.eg or mohamadhamdy@yahoo.com
}

check for updates

Citation: Hendy, O.M.; El Haddad, O.M.; Ghoniem, E.M.; Diab, K.A.;

Khalil, F.O.; Elshemy, E.E.;

Abdelmageed, N.A.; Attia, M.H. The Diagnostic Value of CD11b

Expression on Peripheral Blood

Neutrophils for Detection of

Spontaneous Bacterial Peritonitis.

Gastroenterol. Insights 2021, 12, 17-27.

https://doi.org/10.3390/

gastroent12010003

Received: 7 December 2020

Accepted: 18 January 2021

Published: 20 January 202

Publisher's Note: MDPI stays neutral with regard to jurisdictional claims in published maps and institutional affiliations.

Copyright: (c) 2021 by the authors. Licensee MDPI, Basel, Switzerland. This article is an open access article distributed under the terms and conditions of the Creative Commons Attribution (CC BY) license (https:// creativecommons.org/licenses/by/ $4.0 /)$.

\begin{abstract}
Background: Spontaneous bacterial peritonitis (SBP) is associated with the highest mortality among end-stage cirrhotic liver disease patients. Neutrophil CD11b expression increases on the neutrophil surface within $5 \mathrm{~min}$ of exposure to bacteria. Paracentesis remains the only accepted method for accurate evaluation of patients, with many drawbacks; hence, a diagnostic noninvasive marker with a very high sensitivity and high diagnostic accuracy is very necessary. Aim of the study: to evaluate the neutrophil CD11b as a non-invasive biomarker for the diagnosis of SBP, comparing its sensitivity and specificity to other traditional methods. Patients and Methods: 200 patients who had liver cirrhosis with ascites were recruited to the Hepatology department inpatient wards of the National Liver Institute, Menoufia University. They were divided into Group I: 100 patients with SBP and Group II: 100 patients with non SBP ascites. All studied patients were subjected to full clinical examination, abdominal ultrasound, paracentesis, and laboratory investigations including ascetic fluid (AF) examinations. The CD11b expression and its mean fluorescence intensity (MFI) were assessed on peripheral blood neutrophils by flowcytometry. Results: There was a significant increase in the MFI of CD11b in the SBP group compared to the non SBP group. At cut off $>20$ for MFI of CD11b with a sensitivity of $100 \%$ and specificity of $100 \%$ can discriminate between SBP and non SBP cases followed by ascetic fluid TLC examination at a cut off $0.26\left(\times 10^{3}\right)$ with a sensitivity of $92 \%$, and specificity of $96 \%$, then, AF neutrophil count at cut off $0.25\left(\times 10^{3}\right)$ with a sensitivity of $80 \%$, specificity of $100 \%$, and AF culture examination with a sensitivity of $56 \%$ and specificity of $100 \%$. Conclusion: The measurement of CD11b MFI on peripheral blood neutrophils is a useful non-invasive marker with high sensitivity and specificity to predict SBP compared with other methods. Further large-scale studies are needed to study the value of CD11b MFI level in the SBP follow-up therapy.
\end{abstract}

Keywords: spontaneous bacterial peritonitis (SBP); CD11b; flow cytometer; ascetic fluid

\section{Introduction}

Spontaneous bacterial peritonitis (SBP) is the one of the life-threatening infections that prevails in cirrhotic patients with ascites. It accounts for more than half of all infections [1]. The high incidence of bacterial infections in patients with cirrhosis requires an assessment of their immune defense defects against microorganisms, including increased levels in serum and ascitic fluid cytokines, reduced serum complement levels, and abnormalities 
in the cellular components of the inflammatory response at the circulatory level (monocytes and neutrophils) [2]. Primary peritonitis (PP) is an inflammatory rare sequela of the peritoneal cavity without a known source [3]. Primary pneumococcal peritonitis is a challenge because of its non-specific clinical characters and uncommon existence as intra-abdominal pathogen [4]. Group A Streptococci (GAS) is another rare cause of acute primary peritonitis represented intraoperatively by fibrinous peritonitis and confirmed by microbiological analysis [5]. Cluster differentiation $11 b$ (CD11b) is an alpha subunit of the a2 integrin adhesion molecule; it is expressed mainly on monocytes, macrophages, dendritic cells, neutrophils, natural killer cells, and a subset of $T$ and $B$ lymphocytes [6]. It modulates several key biological functions in innate immune cells [7]. CD11b also has a basic role in the phagocytosis of opsonized particles such as apoptotic cells, iC3b-coated bacteria, and immune complexes which is necessary to restrain unwanted inflammatory immune responses [8]. Neutrophil CD11b (nCD11b) expression increases within 5 min of exposure to bacterial products mainly to lipopolysaccharides present in the wall of gram-negative bacteria such as E. coli [9]. In vitro functional studies of peripheral blood neutrophils had shown defective chemotaxis, phagocytic activity, and intracellular killing capacity which were not sufficiently investigated in relation to the risk of bacterial infection in cirrhotic patients [10]. Paracentesis is a risky technique and performing ascetic fluid (AF) culture examinations is time consuming and not always possible, and the dissociation of neutrophils during transportation to the laboratory may lead to false-negative results [11]. Although a positive AF culture for a pathogen is the gold standard for SBP diagnosis, about $60 \%$ of cases with clinical manifestations indicative of SBP have negative cultures with an AF polymorphonuclear leukocyte (PMNL) count $\geq 250 / \mu \mathrm{L}$ [10]. Moreover, the absence of typical clinical characteristics of SBP makes its identification difficult [12]. Several non-invasive methods were tried in many studies for SBP diagnosis, as alternatives to diagnostic paracentesis, with variable accuracies. However, none of these methods was accurate enough to replace diagnostic paracentesis [13]. The current study was designed to evaluate the neutrophil surface receptor CD11b as a marker for the detection of SBP and to find its sensitivity and specificity in relation to other traditional diagnostic methods.

\section{Subjects and Methods}

This retrospective case-control study was conducted on 200 patients who had liver cirrhosis with ascites. They were selected from the outpatient clinic and inpatient ward of the Hepatology department of the National Liver Institute, Menoufia University and Al Zahra University hospital, during the period from November 2018 to December 2019. According to clinical, radiological, and ascitic fluid examination, the study population was divided into Group I, including the patients with AF infection, and Group II, including those with sterile AF. Ethical committee approval of the National Liver Institute, Menoufia University was obtained, and informed written consents were given from all patients before enrollment in this study.

The inclusion criteria were: age 18 years or older, patients with liver cirrhosis with the presence of ascites by clinical and radiological examination.

The exclusion criteria were: ascites due to any cause other than liver cirrhosis, patients with hepatocellular carcinoma, secondary bacterial peritonitis (surgically treatable source of infection), patient with other source of infection or septicemia, patients with renal failure, and patients on antibiotic treatment or norfloxacin prophylaxis.

All studied patients were subjected to history taking and clinical examination to explore the cause and presence of SBP and abdominal ultrasonography.

Laboratory investigations: Blood sample was divided as five $\mathrm{mL}$ on a plain vacutainer tube to separate serum for viral hepatitis markers, liver and kidney function tests using the Cobas 6000 analyzer * (c501 module, GmbH, Germany), and C-reactive protein (CRP) using the Cobas 6000 analyzer ** (c501 module, Tokyo, Japan). Three $\mathrm{mL}$ of blood was delivered to an EDTA vacutainer tube for complete blood count (CBC) including white blood cell (WBCs) and absolute neutrophil counts (by Sysmex ${ }^{* * *}$ XT 1800i, Tokyo, Japan). 
The remaining sample was put on a 3.8\% citrate solution in a dilution of 1:9 for analysis of coagulation profile as prothrombin time (PT), INR, and activated partial thromboplastin time (APTT). Abdominal paracentesis and AF examinations included WBCs and neutrophil counts, AF total protein, and AF albumin using Cobas 6000 (e 601 module, Germany).

Bacterial culture for $\mathrm{AF}$ and antimicrobial susceptibility: Isolates were plated on blood agar and MacConkey agar (Oxoid Ltd, Wae Road, Basingstoke, Hants, RG248PW, UK). Cultures were then examined macroscopically for colonial morphology and a Gram staining was performed on suspected colonies. All Enterobacteriaceae isolates were selected, then subcultured at $37^{\circ} \mathrm{C}$ overnight on extended spectrum beta lactamase (ESBL) Chroma agar media for confirmation of ESBL strains and further identification tests. Staphylococcus isolates was subcultured on mannitol salt agar. Subcultures were done on Muller Hinton agar. Furthermore, confirmation of the isolates and antibiotic sensitivity was performed using the automated VITEK 2 Compact system (BioMerieux, Inc. (100 Rodolphe street Durham, North Carolina27712, USA)) following the manufacturer's instructions.

Assessment of neutrophils' CD11b expression by flow cytometer: Peripheral blood samples were collected on an EDTA vacutainer tube within $6 \mathrm{~h}$ after paracentesis and before antibiotic therapy; the blood sample was processed within $24 \mathrm{~h}$ after collection for the measurement of $\mathrm{CD} 11 \mathrm{~b}$ expression on neutrophils which are defined by their forward and side scatter characteristics. In each sample, 10,000 cells were analyzed. Purified mouse anti human monoclonal antibody CD11b labeled by phycoerythrin (PE) (Rat/IgG2b, kappa) (provided by BD Bioscience, Germany, USA) ${ }^{* * * *}$ was used. Briefly, $100 \mu \mathrm{L}$ of anticoagulated (EDTA) whole blood was added to the bottom of a $12 \times 75 \mathrm{~mm}$ polystyrene tube along with $5 \mu \mathrm{L}$ of $\mathrm{CD} 11 \mathrm{~b}$ and $5 \mu \mathrm{L}$ of CD41; vortex and incubation were performed for $40 \mathrm{~min}$ in the dark at room temperature; $100 \mu \mathrm{L}$ of reagent $\mathrm{A}$ (formaldehyde) was added to the sample; then, vortex and incubation were performed for $10 \mathrm{~min}$ at room temperature in the dark. A volume of $1 \mathrm{~mL}$ of reagent B (buffer) was added to the sample, and vortex and incubation were performed for $10 \mathrm{~min}$ at room temperature in the dark. Unstained samples were included as controls. Gates were analyzed for the number and percentage of cells. The expression of CD11b and mean fluorescence intensity (MFI) of CD11b was assessed on neutrophils by flow cytometer (Partec CyFlow ${ }^{\circledR}$ Space Flow Cytometer, Sysmex Partec, $\mathrm{GmbH}$, Germany) ${ }^{* * * * *}$ (Figures 1 and 2).
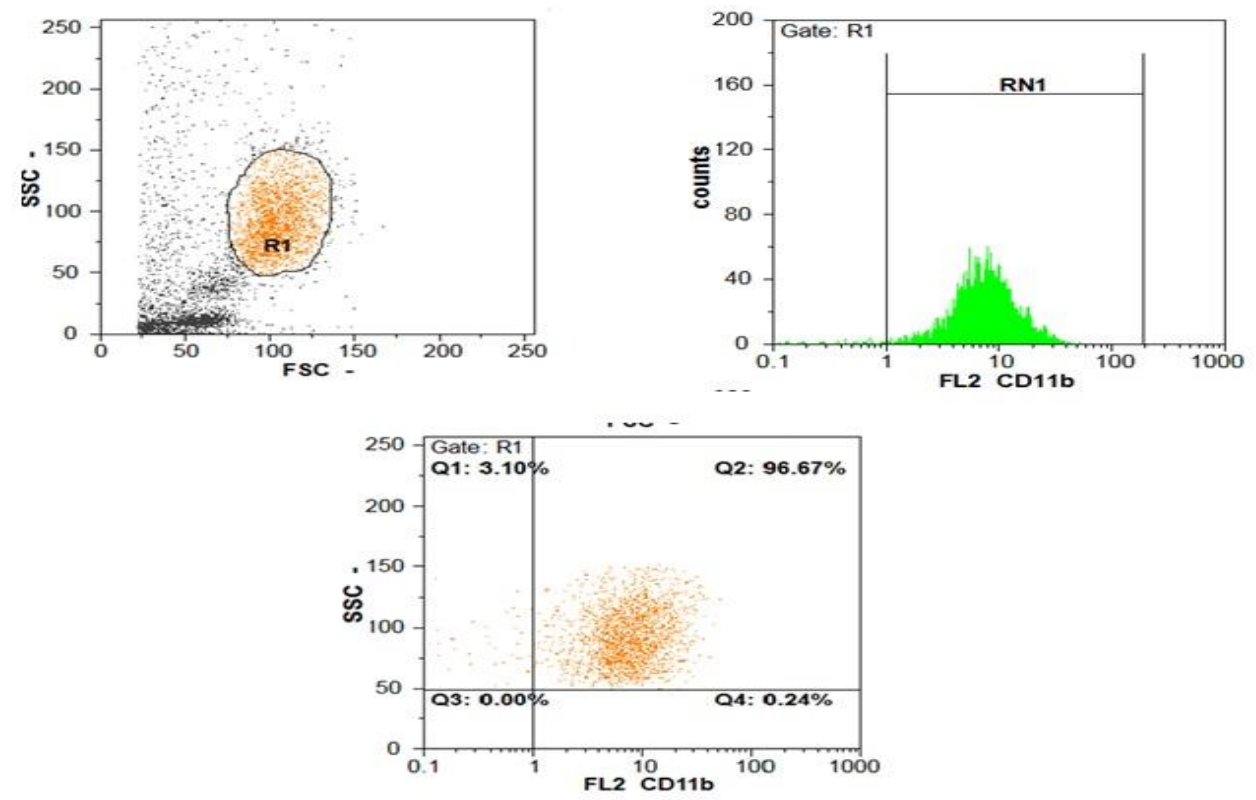

Figure 1. Flow cytometer charts for the CD11b expression on neutrophils and MFI in non SBP patients. 

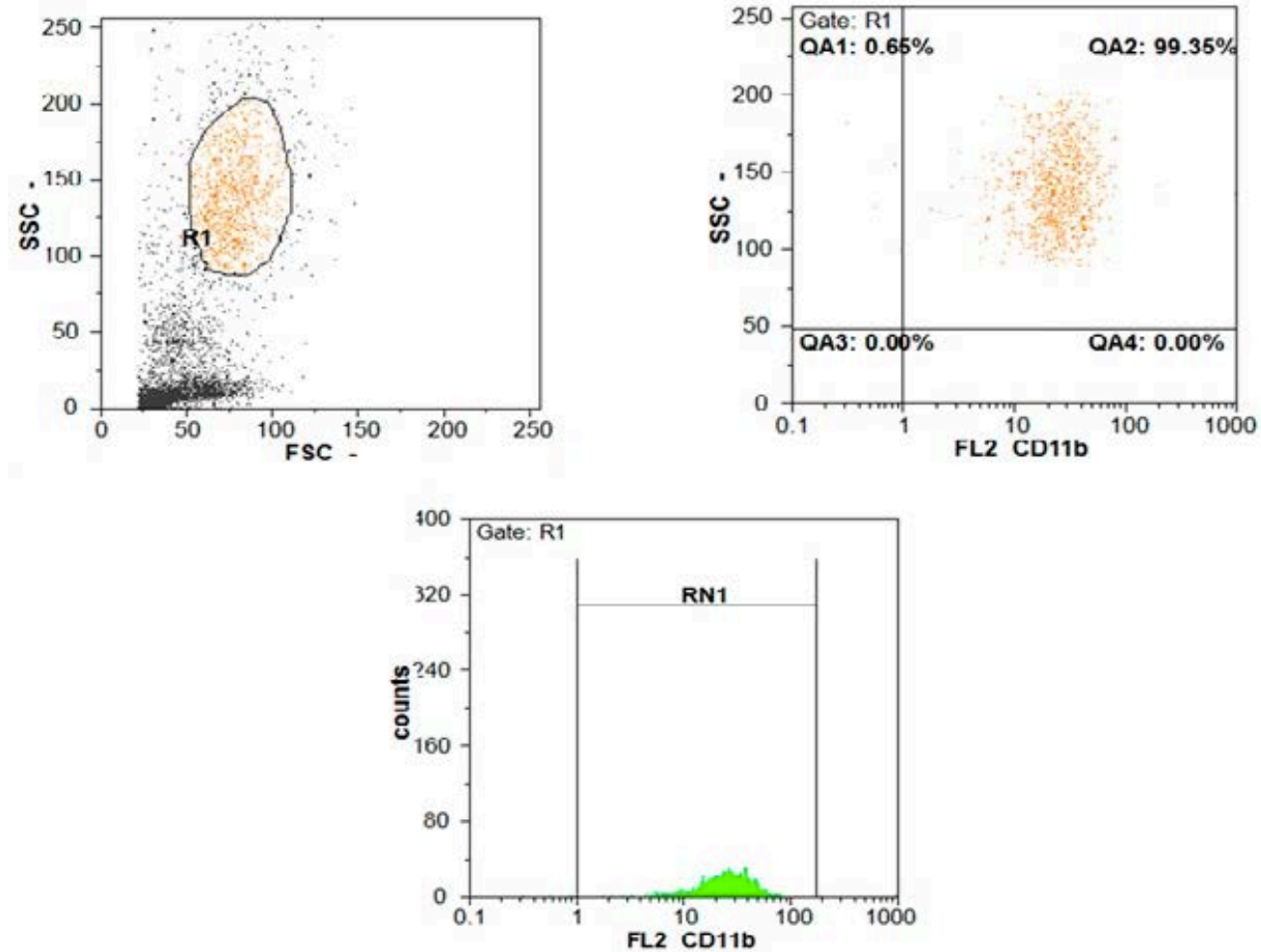

Figure 2. Flow cytometer charts for the CD11b expression on neutrophils and MFI in SBP patients.

* Cobas 6000 c 501 Hitachi High Technologyies Corporation, Tokyo, Japan.

** Cobas 6000 c 601 module, Roche Diagnostics, GmbH, Germany.

*** Sysmex Corporation, Wakinohama-Kaigandori, Chuo-ku, Kobe 651-0073, Japan, Phone: +81-78-265-0500, Fax: +81-78-265-0524, www.sysmex.co.jp.

**** BD Biosciences, 2350 Qume Drive, San Jose, CA 95131, USA, Phone: +877-232-8995.

Becton, and Dickinson Company, 1 Becton Drive- Franklin Lakes, NJ 07417-1880, Phone: +201-847-6800.

***** Manufacturer: Sysmex Partec GmbH, Germany. Am Flugplatz 13, 02828 Görlitz, Germany, Phone: +49-3581-8746-0, Fax: +49-3581-8746-70, info@sysmex-partec.com, www. sysmex-partec.com

Statistical analysis of the data: Data were fed to the computer and analyzed using statistical package of social sciences (IBM SPSS) software package version 20.0. (Armonk, NY: IBM Corp) Qualitative data were described using number and percent. The KolmogorovSmirnov test was used to verify the normality of distribution. Quantitative data were described using the range (minimum and maximum), mean, standard deviation (SD), median, and interquartile range (IQR). The significance of the obtained results was judged at the $5 \%$ level.

\section{Results}

A significant increase $(p<0.05)$ was found in the creatinine and CRP levels while a significant decrease was found in the level of serum albumin in the SBP patient group compared to the non SBP patient group. No significant statistical difference between both groups was detected regarding AST, ALT, GGT, ALP, and T.BIL (Table 1)

There was a significant decrease in platelet count, and a significant increase in WBC count, neutrophils count, INR, and PTT among SBP compared to non SBP patient groups, while no statistically significant difference between both groups was detected in the hemoglobin level (Table 2). 
Table 1. Comparison between liver and kidney function tests and CRP in SPB and non SBP patient groups.

\begin{tabular}{|c|c|c|c|c|}
\hline Parameters & $\begin{array}{c}\text { SBP } \\
(n=100)\end{array}$ & $\begin{array}{l}\text { Non SBP } \\
(n=100)\end{array}$ & Test of Sig. & $p$ \\
\hline $\begin{array}{c}\text { AST (IU/L) } \\
\text { Min-Max. } \\
\text { Median (IQR) }\end{array}$ & $\begin{array}{c}26.0-200.0 \\
59.0(47.0-100.0)\end{array}$ & $\begin{array}{c}19.0-163.0 \\
77.50(54.0-136.0)\end{array}$ & $\mathrm{U}=1036.50$ & 0.141 \\
\hline $\begin{array}{c}\text { ALT (IU/L) } \\
\text { Min-Max. } \\
\text { Median (IQR) }\end{array}$ & $\begin{array}{c}18.0-200.0 \\
51.50(36.0-80.0)\end{array}$ & $\begin{array}{c}19.0-145.0 \\
68.0(43.0-107.0)\end{array}$ & $\mathrm{U}=1044.50$ & 0.156 \\
\hline $\begin{array}{c}\text { ALP (IU/L) } \\
\text { Min-Max. } \\
\text { Median (IQR) }\end{array}$ & $\begin{array}{c}29.0-260.0 \\
56.0(49.0-88.0)\end{array}$ & $\begin{array}{c}39.0-950.0 \\
60.0(50.0-98.0)\end{array}$ & $\mathrm{U}=1174.50$ & 0.602 \\
\hline $\begin{array}{l}\text { GGT (IU/L) } \\
\text { Min-Max. } \\
\text { Median (IQR) }\end{array}$ & $\begin{array}{c}11.0-200.0 \\
31.0(19.0-55.0)\end{array}$ & $\begin{array}{c}11.0-115.0 \\
45.0(15.0-67.0)\end{array}$ & $\mathrm{U}=1019.50$ & 0.112 \\
\hline $\begin{array}{l}\text { T.BIL (mg/dL) } \\
\text { Min-Max. } \\
\text { Median (IQR) }\end{array}$ & $\begin{array}{c}1.50-15.0 \\
3.05(2.30-4.0)\end{array}$ & $\begin{array}{c}0.90-6.0 \\
2.70(1.90-4.0)\end{array}$ & $\mathrm{U}=1030.50$ & 0.130 \\
\hline $\begin{array}{l}\text { T.P }(g / d L) \\
\text { Min-Max. } \\
\text { Mean } \pm \text { SD. }\end{array}$ & $\begin{array}{c}4.40-6.80 \\
5.80 \pm 0.50\end{array}$ & $\begin{array}{c}4.30-8.70 \\
5.97 \pm 0.73\end{array}$ & $t=1.350$ & 0.180 \\
\hline $\begin{array}{l}\text { S. Albumin }(\mathrm{g} / \mathrm{dL}) \\
\text { Min-Max. } \\
\text { Mean } \pm \text { SD. }\end{array}$ & $\begin{array}{c}1.50-3.20 \\
2.41 \pm 0.39\end{array}$ & $\begin{array}{c}1.60-3.50 \\
2.65 \pm 0.46\end{array}$ & $t=2.724$ & 0.008 \\
\hline $\begin{array}{l}\text { Urea }(\mathrm{mg} / \mathrm{dL}) \\
\text { Min-Max. } \\
\text { Median (IQR) }\end{array}$ & $\begin{array}{c}22.0-235.0 \\
75.50 \\
(49.0-115.0)\end{array}$ & $\begin{array}{c}34.0-226.0 \\
75.0(60.0-86.0)\end{array}$ & $\mathrm{U}=1241.0$ & 0.950 \\
\hline $\begin{array}{c}\text { Creatinine }(\mathrm{mg} / \mathrm{dL}) \\
\text { Min-Max. } \\
\text { Median (IQR) }\end{array}$ & $\begin{array}{c}0.60-6.0 \\
1.80(1.10-2.60)\end{array}$ & $\begin{array}{c}0.60-1.80 \\
1.10(0.90-1.40)\end{array}$ & $\mathrm{U}=613.50$ & $<0.001$ \\
\hline $\begin{array}{l}\mathrm{CRP}(\mathrm{mg} / \mathrm{dL}) \\
\text { Min-Max. } \\
\text { Mean } \pm \text { SD. }\end{array}$ & $\begin{array}{c}24.55-169.89 \\
78.95 \pm 35.28\end{array}$ & $\begin{array}{c}3.80-23.34 \\
12.62 \pm 5.34\end{array}$ & $t=13.144$ & $<0.001$ \\
\hline
\end{tabular}

$t$ : Student $t$-test; $\mathrm{U}$ : Mann Whitney test; $p$ : is statistically significant at $<0.05$.

There was a significant decrease in ascetic fluid total protein and albumin levels in the SBP patient group compared to the non SBP patient group as shown in (Table 3). The WBCs in ascetic fluid was significantly increased in SBP patients and no statistically significant difference between both groups was found regarding the SAAG.

The mean fluorescence intensity (MFI) of CD11b was significantly higher $(p<0.001)$ in the SBP patient group compared to the non SBP patient group, while the surface expression of CD11b on neutrophils showed no significant difference (Table 4).

Table 2. Comparison between CBC and coagulation profile in SBP and non SBP patient groups.

\begin{tabular}{ccccc}
\hline Parameters & SBP $(n=\mathbf{1 0 0})$ & Non SBP $(\boldsymbol{n = 1 0 0 )}$ & $\boldsymbol{t}$-test & $p$ \\
\hline HB $(\mathrm{g} / \mathrm{dL})$ & & & & \\
Min-Max. & $7.80-13.50$ & $7.80-15.0$ & 1.819 & 0.072 \\
Mean \pm SD. & $10.19 \pm 1.51$ & $10.80 \pm 1.80$ & & \\
\hline Platelet $\left(10^{3}\right.$ & & & & \\
cell $/ \mu \mathrm{L})$ & & & & \\
Min-Max. & $35.0-137.0$ & $56.0-258.0$ & & $<0.001$ \\
Mean \pm SD. & $80.36 \pm 22.34$ & $161.8 \pm 56.24$ & \\
\hline
\end{tabular}


Table 2. Cont.

\begin{tabular}{|c|c|c|c|c|}
\hline Parameters & $\operatorname{SBP}(n=100)$ & Non SBP $(n=100)$ & $t$-test & $p$ \\
\hline $\begin{array}{c}\text { WBCs }\left(10^{3} \text { cell } / \mu \mathrm{L}\right) \\
\text { Min-Max. } \\
\text { Mean } \pm \text { SD. }\end{array}$ & $\begin{array}{c}5.30-28.0 \\
12.92 \pm 5.88\end{array}$ & $\begin{array}{c}3.50-12.0 \\
7.13 \pm 2.11\end{array}$ & 6.553 & $<0.001$ \\
\hline $\begin{array}{c}\text { Neutrophil (\%) } \\
\text { Min-Max. } \\
\text { Mean } \pm \text { SD. }\end{array}$ & $\begin{array}{c}50.0-90.0 \\
69.54 \pm 9.57\end{array}$ & $\begin{array}{c}50.0-88.0 \\
68.78 \pm 10.44\end{array}$ & 0.379 & 0.705 \\
\hline $\begin{array}{l}\text { Neutrophil count } \\
\left(10^{3} \text { cell } / \mu \mathrm{L}\right) \\
\text { Min-Max. } \\
\text { Mean } \pm \text { SD. }\end{array}$ & $\begin{array}{c}3.53-18.48 \\
8.98 \pm 4.19\end{array}$ & $\begin{array}{c}2.46-9.0 \\
4.86 \pm 1.52\end{array}$ & 6.543 & $<0.001$ \\
\hline $\begin{array}{c}\text { PT (INR) } \\
\text { Min-Max. } \\
\text { Mean } \pm \text { SD. }\end{array}$ & $\begin{array}{c}1.12-3.90 \\
2.37 \pm 0.69\end{array}$ & $\begin{array}{c}1.10-3.50 \\
1.61 \pm 0.40\end{array}$ & 6.742 & $<0.001$ \\
\hline $\begin{array}{c}\text { PTT (sec.) } \\
\text { Min-Max. } \\
\text { Mean } \pm \text { SD. }\end{array}$ & $\begin{array}{c}22.0-48.0 \\
32.94 \pm 6.02\end{array}$ & $\begin{array}{c}33.0-46.0 \\
40.35 \pm 3.07\end{array}$ & 7.760 & $<0.001$ \\
\hline
\end{tabular}

Table 3. Comparison between ascetic fluid examination parameters in SPB and non SBP patient groups.

\begin{tabular}{|c|c|c|c|c|}
\hline Parameters & $\begin{array}{c}\text { SBP } \\
(n=100)\end{array}$ & $\begin{array}{l}\text { Non SBP } \\
(n=100)\end{array}$ & Test of Sig. & $p$ \\
\hline \multicolumn{5}{|l|}{$\begin{array}{l}\text { AF total protein } \\
(\mathrm{g} / \mathrm{dL})\end{array}$} \\
\hline Min-Max. & $0.50-2.0$ & $1.50-3.0$ & \multirow{2}{*}{$t=15.607$} & \multirow{2}{*}{$<0.001$} \\
\hline Mean \pm SD & $1.17 \pm 0.41$ & $2.32 \pm 0.32$ & & \\
\hline \multicolumn{5}{|l|}{ AF Albumin (g/dL) } \\
\hline Min-Max. & $0.20-1.10$ & $0.30-1.90$ & \multirow{2}{*}{$t=8.071$} & \multirow{2}{*}{$<0.001$} \\
\hline Mean \pm SD & $0.64 \pm 0.25$ & $1.14 \pm 0.36$ & & \\
\hline \multicolumn{5}{|l|}{ SAAG } \\
\hline Min-Max. & $1.0-2.50$ & $1.10-2.60$ & \multirow[b]{2}{*}{$t=1.3$} & \multirow[b]{2}{*}{0.18} \\
\hline Mean \pm SD & $1.6 \pm 0.39$ & $1.50 \pm 0.35$ & & \\
\hline \multicolumn{5}{|l|}{ WBCs $\left(10^{3}\right.$ cell $\left./ \mu \mathrm{L}\right)$} \\
\hline Min-Max. & $0.09-15.20$ & $0.06-0.29$ & \multirow{2}{*}{$\mathrm{U}=75.50$} & \multirow[b]{2}{*}{$<0.001$} \\
\hline Median (IQR) & $3.45(1.2-4.90)$ & $0.16(0.10-0.20)$ & & \\
\hline
\end{tabular}

Table 4. Comparison between SBP and non SBP patient groups regarding CD11b.

\begin{tabular}{ccccc}
\hline Parameters & $\begin{array}{c}\text { SBP } \\
(n=\mathbf{1 0 0})\end{array}$ & $\begin{array}{c}\text { Non SBP } \\
(\boldsymbol{n}=\mathbf{1 0 0})\end{array}$ & Test of Sig. & $p$ \\
\hline CD11b & & & & \\
expression & & & & \\
Min-Max. & $95.0-99.50$ & $96.0-99.50$ & $t=$ & $>0.05$ \\
Mean \pm SD. & $97.82 \pm 1.11$ & $98.45 \pm 0.70$ & 2.382 & $<0.001$ \\
\hline CD11b MFI & & & & \\
Min-Max. & $20.50-96.0$ & $8.0-20.0$ & $\mathrm{U}=60.0$ & \\
Median (IQR) & $48.50(39.0-58.0)$ & $\begin{array}{c}13.0 \\
(11.50-16.80)\end{array}$ & & \\
\hline
\end{tabular}

At a cut off value of 20 for MFI of CD11b (AUC $=1, p<0.001$ ), and a sensitivity of $100 \%$ and specificity of $100 \%$, the MFI of CD11b could discriminate between SBP and non SBP cases followed by ascitic fluid TLC at a cut off of $0.26\left(\times 10^{3}\right)($ AUC $=0.97, p<0.001)$, 
a sensitivity of $92 \%$, and a specificity of $96 \%$, followed by an AF neutrophil count at a cut off of $0.25\left(\times 10^{3}\right)(\mathrm{AUC}=0.94, p<0.001)$ with a sensitivity of $80 \%$, and specificity of $100 \%$; the last was AF culture (AUC $=0.78$ ) by a sensitivity of $56 \%$ and specificity of $100 \%$ (Table 5 and Figure 3).

Table 5. Sensitivity and specificity for MFI of CD11b, AF-TLC, AF neutrophil count, and culture results to discriminate SBP cases from non SBP cases.

\begin{tabular}{|c|c|c|c|c|c|c|c|c|c|}
\hline & \multirow{2}{*}{ AUC } & \multirow{2}{*}{$p$} & \multicolumn{2}{|c|}{$95 \% \mathrm{CI}$} & \multirow{2}{*}{ Cut off $\#$} & \multirow{2}{*}{ Sensitivity } & \multirow{2}{*}{ Specificity } & \multirow{2}{*}{ PPV } & \multirow{2}{*}{ NPV } \\
\hline & & & LL & UL & & & & & \\
\hline $\begin{array}{c}\text { MFI of } \\
\text { CD11b \% }\end{array}$ & 1.000 & $<0.001 *$ & 1.000 & 1.000 & $>20$ & 100.0 & 100.0 & 100.0 & 100.0 \\
\hline $\begin{array}{c}\text { AF- TLC } \\
\left(\times 10^{3} / \mathrm{mm}^{2}\right)\end{array}$ & 0.970 & $<0.001 *$ & 0.930 & 1.009 & $>0.26$ & 92.0 & 96.00 & 95.8 & 92.3 \\
\hline $\begin{array}{c}\mathrm{AF} \\
\text { neutrophils } \\
\left(\times 10^{3} \mathrm{~mm}^{2}\right)\end{array}$ & 0.943 & $<0.001^{*}$ & 0.898 & 0.988 & $>0.25$ & 80.0 & 100.0 & 100.0 & 83.3 \\
\hline AF culture & 0.780 & $<0.001^{*}$ & 0.686 & 0.874 & - & 56.0 & 100.0 & 100.0 & 69.4 \\
\hline
\end{tabular}

AUC: Area under the curve; $p$ value: Probability value; CI: Confidence intervals. NPV: Negative predictive value; PPV: Positive predictive value. *: Statistically significant at $p<0.05$; \# Cut off was chosen according to Youden index.

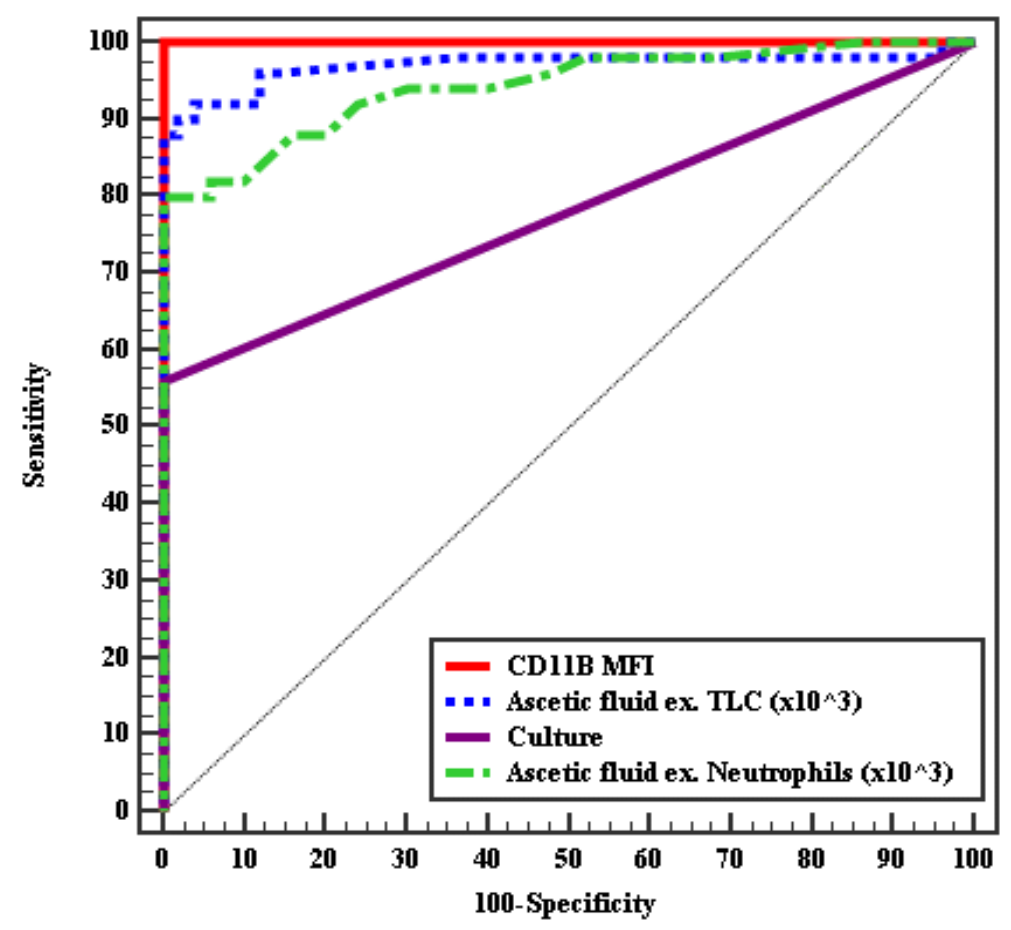

Figure 3. ROC curve for CD11b MFI, ascetic fluid TLC $\left(\times 10^{3}\right)$, culture, and AF neutrophils $\left(\times 10^{3}\right)$ to diagnose SBP from non SBP cases.

\section{Discussion}

Bacterial translocation from the gut is the main pathogenic mechanism underlying SBP. Liver cirrhosis is associated with changes in the quantity and quality of the microbiota, with the subsequent disturbance of the gut barrier function and immune response to the microbe translocation leading to the occurrence of the SBP [14].

Diagnostic paracentesis and AF analysis are essential for all patients admitted with ascites (especially newly developed ascites). Although the procedure is easy, it may be complicated with bleeding and infection. Moreover, AF culture examination is time consuming and not always possible in the emergency setting. Hence, a cutoff level of AF- 
PMN count equal or more than 250 cells $/ \mu \mathrm{L}$ is considered diagnostic for SBP, according to the current guidelines [15].

Nevertheless, false-negative results may occur due to the dissolution of polymorph neutrophils (PMNs) during transportation to the laboratory. Moreover, the automated counting of PMN in AF is usually inaccurate due to the low cell count and presence of visible components in the AF. Manual measurement of the AF-PMNs is operator-dependent, making quality control difficult, and this can hinder the diagnosis [15].

SBP is associated with a high mortality; thus, a diagnostic marker with a very high sensitivity and high diagnostic accuracy is necessary to reduce antimicrobial unnecessary treatment and hospitalization. Therefore, the recent research is focusing on using flowcytometric technology as a rapid and non-invasive method in diagnosing infections. Therefore, this study aimed to evaluate the neutrophil CD11b as a noninvasive biomarker for the detection of SBP and to find its sensitivity and specificity in relation to other traditional methods. Our study was conducted with 200 patients who had liver cirrhosis with ascites. They were divided into: Group I, including the patients with AF infection, and Group II, including those with sterile AF. In the present study, the serum albumin level was significantly lower in SBP patients compared to cirrhotic patients without SBP. This agrees with the results of the study conducted by Verma et al. (2017) [16], and also with those in a study by Huang et al. (2011) [17]. Using the cutoff point for a serum albumin level of $2.85 \mathrm{~g} / \mathrm{dL}$ as a predictor for the recurrence of SBP, the sensitivity was $70.2 \%$ and the specificity was $76.3 \%$. In contrast, Metwally et al. (2018) [18] found that there was no significant difference in the albumin level between the two groups; however, our results are in line with the fact that SBP develops mainly in advanced cirrhotic malnourished patients with lower albumin level [19]. Moreover, albumin has an antioxidant function and protects the body from the oxidative stress of infection [20].

In this study, there is a statistically significant increase in the level of serum creatinine and the CRP level among SBP patients; our findings agree with Metwally et al.'s (2018) [18] study regarding these two parameters. Although CRP is a well-recognized parameter for detecting infection or inflammation in the general population, a study by Pieri et al. (2014) [21] reported that the basal CRP level is generally higher in patients with cirrhosis than in patients without cirrhosis. CRP level increases during bacterial infections, but CRP may be decreased in severe liver disease due to the underlying liver dysfunction (CRP produced from hepatocytes). For this reason, CRP has a weak predictive value for infection and prognosis in patients with decompensated/ advanced cirrhosis.

The current study showed a significant thrombocytopenia, and a significant increase in WBCs count, neutrophils count, INR, and PTT among SBP over non SBP patient groups, and no statistically significant difference between the SBP and non SBP groups in regards to hemoglobin level. This agrees with Metwally et al. (2018) [18] and Heikl et al. (2018) [22]. The low platelet count is common in chronic liver disease, because it is either due to the increase in the turnover of the platelets as a result of splenic sequestration, or the decrease in the platelet production due to the decrease of thrombopoietin synthesis by the liver. Thrombocytopenia has been used as an indirect indicator of portal hypertension and liver disease severity [23]. Moreover, thrombocytopenia was used as a predictor of SBP with low AF protein levels, because infections, especially sepsis, produce thrombocytopenia [24].

By comparing patients with AF infection and those with sterile AF, there was a significant decrease in the AF infection group related to total protein and albumin levels, while both groups had comparable results regarding SAAG. Our results agree with both Verma et al.'s (2017) [16] and Heikl et al.'s (2018) [22] regarding these parameters. Interestingly, Abdel-Razik et al. (2016) [25] reported that patients with SBP have an increase in AF total protein which has an important role in the inflammatory process in SBP. In contrast, Ali and Mohamed (2019) [26] found no statistically significant difference between SBP and non SBP patients in both the AF total protein and AF albumin level.

The opsonic activity of AF has been shown to correlate closely with the fluid's protein and albumin concentration. A decreased level of albumin and protein in AF decreases 
opsonic activity and therefore decreases the protection from bacterial infection. Fluids with $<1.0 \mathrm{~g} / \mathrm{dL}$ of protein have been reported to have diminished opsonic activity and therefore high susceptibility to SBP [27].

Our study revealed that the mean value of SAAG was $>1.1 \mathrm{~g} / \mathrm{dL}$ in both SBP and non-SBP groups, but without a significant difference. This confirms that the etiology of ascites was portal hypertension in these patients. This finding is in concordance with Heikl et al.'s (2018) [22] study, which suggested that SAAG levels are $>1$ in portal hypertension induced ascites.

Additionally, the AF TLC count was significantly higher in cirrhotic SBP patients compared to cirrhotic non SBP patients; this result is in line with the result reported by Heikl et al. (2018) [22], and Ali and Mohamed, (2019) [26]. In the same manner, Yildirim et al. (2005) [28] and Jansen (1997) [29] reported a higher ascetic TLC in SBP patients than in non SBP patients.

In our patients, the mean fluorescence intensity (MFI) of CD11b was significantly higher $(p<0.001)$ in SBP compared to non SBP patients, while the surface expression of $\mathrm{CD} 11 \mathrm{~b}$ on neutrophils showed no significant difference. This goes in line with the fact that $\mathrm{CD} 11 \mathrm{~b}$ is an $\alpha$-subunit of the $\beta 2$-integrin adhesion molecule which, under normal circumstances, is expressed at a very low concentration on the surface of non-activated neutrophils; this expression increases exponentially within a few minutes after activation of the neutrophils by the bacteria and/or its endotoxins (Khan et al., 2018) [6]. Moreover, Stålhammar et al. (2016) [7] stated that CD11b regulates numerous basic biological functions in innate immune cells that mediate the generation of type I interferon.

A study done by Gonzalez et al. (1998) [30] has shown that about 95\% of the total content of the resting neutrophils CD11b is in the form of intracellular storage vesicles, with only $5 \%$ of CD11b expressed on the cell surface. Upon stimulation of the neutrophils, the exocytosis of these secretory vesicles occurs with a consequent enhanced CD11b expression. Nakstad et al. (2016) [31] stated that neutrophil CD11b has been found to be a promising marker for diagnosis of early infections. Two hours after the onset of neutrophil stimulation, $\mathrm{CD} 11 \mathrm{~b}$ on granulocytes was the inflammatory marker with the highest specificity $(100 \%)$ at a cutoff value that gave the test at least a $95 \%$ sensitivity, which is excellent.

\section{Limitations}

The limitations of this study include the small number of study population. Therefore, a larger controlled study will be needed. Moreover, we did not test for serum markers other than CD11b, and it is not clear whether the in vitro behavior of peripheral blood neutrophils adequately correlates with the in vivo activity. Finally, it would have been more appropriate if we had added one more group of CDs with infections other than SBP in cirrhotic subjects to assess the specificity of CD11b for SBP.

\section{Conclusions}

Due to the short time for the detection of CD11b-MFI on peripheral blood neutrophils, it can be implied as new biomarker to discriminate between SBP and non SBP cases with a high sensitivity and specificity superior to AF TLC, and neutrophil count and AF culture, which is time consuming and gives false negative results. Thus, a noninvasive rapid biomarker with a very high sensitivity and high diagnostic accuracy is quite necessary to reduce unnecessary antimicrobial treatment and hospitalization. Further large studies are needed to confirm the ability to use CD11b measurement in the SBP follow-up therapy.

Author Contributions: The author contributed in the process of the research synthesis in the following roles, Conceptualization, O.M.H. and O.M.E.H., methodology, O.M.H. and O.M.E.H. Validation, E.E.E. and N.A.A.; formal analysis: paid service followed by E.M.G.; investigation, K.A.D. and F.O.K.; resources, K.A.D. and F.O.K.; data curation, M.H.A. and, F.O.K. Writing-original draft preparation, E.M.G., E.E.E. and N.A.A.; writing—review and editing: M.H.A.; visualization, M.H.A. Supervision, O.M.H. and O.M.E.H.; project administration, O.M.H. All authors have read and agreed to the published version of the manuscript. 
Funding: This research received no external funding.

Acknowledgments: No grant or financial support of any of the authors is related to this work.

Conflicts of Interest: The authors have no conflicts to disclose.

\section{References}

1. Elsadek, H.M.; Elhawari, S.A.; Mokhtar, A. A novel serum index for accurate diagnosis of spontaneous bacterial peritonitis in cirrhotic patients without other infections. Egypt Liver J. 2020, 10, 10. [CrossRef]

2. Fiuza, C.; Salcedo, M.; Clemente, G.; Tellado, J.M. In vivo neutrophil dysfunction in cirrhotic patients with advanced liver disease. J. Infect. Dis. 2000, 182, 526-533. [CrossRef] [PubMed]

3. Khilji, M.F. Primary peritonitis-A forgotten entity. Eur. J. Pediatr. Surg. Rep. 2015, 3, 27-29. [CrossRef] [PubMed]

4. Cortese, F.; Fransvea, P.; Saputelli, A.; Ballardini, M.; Baldini, D.; Gioffre, A.; Marcello, R.; Sganga, G. Streptococcus pneumoniae primary peritonitis mimicking acute appendicitis in an immunocompetent patient: A case report and review of the literature. J. Med. Case Rep. 2019, 13, 126. [CrossRef] [PubMed]

5. Malota, M.; Felbinger, T.W.; Ruppert, R.; Nüssler, N.C. Group A Streptococci: A rare and often misdiagnosed cause of spontaneous bacterial peritonitis in adults. Int. J. Surg. Case Rep. 2015, 6, 251-255. [CrossRef] [PubMed]

6. Khan, S.Q.; Khan, I.; Gupta, V. CD11b activity modulates pathogenesis of lupus nephritis. Front. Med. 2018, 5, 52. [CrossRef] [PubMed]

7. Stålhammar, M.E.; Sindelar, R.; Douhan Håkansson, L. Neutrophil receptor response to bacterial N-formyl peptides is similar in term newborn infants and adults in contrast to IL-8. Scand. J. Immunol. 2016, 84, 332-337. [CrossRef] [PubMed]

8. Phillipson, M.; Heit, B.; Colarusso, P.; Liu, L.; Ballantyne, C.M.; Kubes, P. Intraluminal crawling of neutrophils to emigration sites: A molecularly distinct process from adhesion in the recruitment cascade. J. Exp. Med. 2006, 203, 2569-2575. [CrossRef]

9. Qiu, X.; Li, J.; Yang, X.; Tang, J.; Shi, J.; Tong, Y.; Qu, Y.; Mu, D. Is neutrophil CD11b a special marker for the early diagnosis of sepsis in neonates? A systematic review and meta-analysis. BMJ Open 2019, 9, e025222. [CrossRef]

10. Wandall, J.H. Function of polymorphonuclear neutrophilic leucocytes: Comparison of leucocytes from blood and exudate in healthy volunteers. Acta Pathol. Microbiol. Scand. Ser. C Immunol. 2009, 90, 7-13. [CrossRef]

11. Runyon, B.A. Introduction to the revised american association for the study of liver diseases practice guideline management of adult patients with ascites due to cirrhosis 2012. Hepatology 2013, 57, 1651-1653. [CrossRef] [PubMed]

12. Attar, B.M.; George, M.; Ion-Nedelcu, N.; Ramadori, G.; Thiel, D.H.V. Disease dependent qualitative and quantitative differences in the inflammatory response to ascites occurring in cirrhotics. WJH 2014, 6, 85. [CrossRef] [PubMed]

13. Usui, S.; Ebinuma, H.; Chu, P.-S.; Nakamoto, N.; Yamagishi, Y.; Saito, H.; Kanai, T. Detection of bacterial DNA by in situ hybridization in patients with decompensated liver cirrhosis. BMC Gastroenterol. 2017, 17, 106. [CrossRef] [PubMed]

14. Fiore, M.; Maraolo, A.E.; Gentile, I.; Borgia, G.; Leone, S.; Sansone, P.; Passavanti, M.B.; Aurilio, C.; Pace, M.C. Nosocomial spontaneous bacterial peritonitis antibiotic treatment in the era of multi-drug resistance pathogens: A systematic review. World J. Gastroenterol. 2017, 23, 4654-4660. [CrossRef]

15. Runyon, B. Strips and Tubes: Improving the diagnosis of spontaneous bacterial peritonitis. Hepatology 2003, 37, 745-747. [CrossRef]

16. Verma, R.K.; Giri, R.; Agarwal, M.; Srivastava, V. To study the relation between spontaneous bacterial peritonitis and serum ascitis albumin gradient in chronic liver disease patients. Int. J. Res. Med. Sci. 2017, 5, 3654. [CrossRef]

17. Huang, C.-H.; Lin, C.-Y.; Sheen, I.-S.; Chen, W.-T.; Lin, T.-N.; Ho, Y.-P.; Chiu, C.-T. Recurrence of spontaneous bacterial peritonitis in cirrhotic patients non-prophylactically treated with norfloxacin: Serum Albumin as an easy but reliable predictive factor: Recurrence of spontaneous bacterial peritonitis. Liver Int. 2011, 31, 184-191. [CrossRef]

18. Metwally, K.; Fouad, T.; Assem, M.; Abdelsameea, E.; Yousery, M. Predictors of spontaneous bacterial peritonitis in patients with cirrhotic ascites. J. Clin. Transl. Hepatol. 2018, 6, 1-5. [CrossRef]

19. Hassan, M.; Moonka, D. Spontaneous bacterial peritonitis. In Liver Disease: A Clinical Casebook; Cohen, S.M., Davitkov, P., Eds.; Springer International Publishing: Cham, Switzerland, 2019; pp. 37-45.

20. Setoyama, H.; Tanaka, M.; Sasaki, Y. Treatment of spontaneous bacterial peritonitis. In Clinical Investigation of Portal Hypertension; Obara, K., Ed.; Springer Singapore: Singapore, China, 2019; pp. 517-522.

21. Pieri, G.; Agarwal, B.; Burroughs, A.K. C-reactive protein and bacterial infection in cirrhosis. Ann. Gastroenterol. 2014, 27, 113-120.

22. Heikl, A.; El-Nokeety, M.; Roshdy, E.; Mohey, A. Ascitic calprotectin as a diagnostic marker for spontaneous bacterial peritonitis in Hepatitis C virus cirrhotic egyptian patients. Egypt J. Int. Med. 2018, 30, 1. [CrossRef]

23. Sheikh, M.; Raoufi, R.; Atla, P.; Riaz, M.; Oberer, C.; Moffett, M. Prevalence of cirrhosis in patients with Thrombocytopenia who receive bone marrow biopsy. Saudi J. Gastroenterol. 2012, 18, 257. [CrossRef] [PubMed]

24. Venkata, C.; Kashyap, R.; Farmer, J.C.; Afessa, B. Thrombocytopenia in adult patients with sepsis: Incidence, risk factors, and its association with clinical outcome. J. Intensiv. Care 2013, 1, 9. [CrossRef] [PubMed]

25. Abdel-Razik, A.; Mousa, N.; Elhammady, D.; Elhelaly, R.; Elzehery, R.; Elbaz, S.; Eissa, M.; El-Wakeel, N.; Eldars, W. Ascitic fluid calprotectin and serum procalcitonin as accurate diagnostic markers for spontaneous bacterial peritonitis. Gut. Liver 2016, 10, 624-631. [CrossRef] [PubMed] 
26. Ali, S.; Mohamed, N.A.E.-G. The value of ascitic fluid calprotectin and calprotectin-to-albumin ratio in the diagnosis and prognosis of spontaneous bacterial peritonitis. Sci. J. Al Azhar Med. Fac. Girls 2019, 3, 527. [CrossRef]

27. Paul, K. To study the incidence, predictive factors and clinical outcome of spontaneous bacterial peritonitis in patients of cirrhosis with ascites. JCDR 2015, 9, OC09. [CrossRef]

28. Yildirim, B.; Sari, R.; Isci, N. Patients with spontaneous bacterial peritonitis, and malignant and cirrhotic ascites. J. Natl. Med. Assoc. 2005, 97, 276-280.

29. Jansen, P.L.M. Spontaneous bacterial peritonitis detection, treatment and prophylaxis in patients with liver cirrhosis. Neth. J. Med. 1997, 51, 123-128. [CrossRef]

30. Gonzalez-Amaro, R.; Diaz-Gonzalez, F.; Sanchez-Madrid, F. Adhesion molecules in inflammatory diseases. Drugs 1998, 56, 977-988. [CrossRef]

31. Nakstad, B.; Sonerud, T.; Solevag, A.L. Early detection of neonatal group B Streptococcus sepsis and the possible diagnostic utility of IL-6, IL-8, and CD11b in a human umbilical cord blood in vitro model. IDR 2016, 9, 171-179. [CrossRef] 